\title{
A MULTIPLE INDICATORS MULTIPLE CAUSES MODEL OF BEHAVIORAL CONSEQUENCES OF HOTEL GUESTS
}

Published in "Tourism management perspectives", 2019, vol. 30, pp. 197-207, which should be cited to refer to this work

DOI : $10.1016 / j$.tmp.2019.02.014 


\begin{abstract}
This study aims to examine the effects of a set of covariates, including culture, sociodemographic, and travel behavioral patterns, on behavioral consequences of hotel guests. We developed a Multiple Indicators Multiple Causes (MIMIC) model to test the effects of these covariates on hotel guests' perceived service quality, customer satisfaction, customer loyalty, and complaint intentions. Using a sample of 2,267 hotel guests in Hong Kong during the period 2010-2015, we verified the four-factor structure of the behavioral consequences of hotel guests in the presence of seven covariates. The results showed that culture, gender, age, education, income, and travel experience predicted the behavioral consequences of hotel guests. After controlling for the effects of each of the four constructs in the model, we detected the direct effects of six covariates, except gender, on the indicators of the four constructs.
\end{abstract}

Keywords: Service quality, customer satisfaction, customer loyalty, complaint intention, Multiple Indicators Multiple Causes (MIMIC) model 


\section{INTRODUCTION}

Consumer behavior research in tourism and hospitality has long been devoted to the study of the antecedents and consequences of consumer decision-making, ranging from patronizing a restaurant to vacationing at a destination (Meng, Tepanon, \& Uysal, 2008; Kim \& Eves, 2012). This strand of research has focused on a series of cognitive and behavioral consequences, such as perceived service quality, tourist satisfaction, customer loyalty as well as behavioral intentions (Song et al., 2012; Yoon \& Uysal, 2005). The implications lie with the fact that these behavioral consequences indicate service performance of tourism suppliers as well as the competitiveness of tourist destinations (Chen, Chen, \& Lee, 2011; Kozak \& Rimmington, 1999; Song et al., 2012). For instance, various customer satisfaction indices have been developed, aiming at gauging service performance of different industrial sectors to make it comparable across different hospitality sectors as well as different destinations as a whole (Anderson \& Fornell, 2000; Chan et al., 2003; Fornell, 1992; Song et al., 2012).

Behavioral consequence constructs are heterogeneous in relation to consumer characteristics, which, though, has yet to be factored into tourist behavior models. Consumers differ by culture, sociodemographic, and behavioral patterns. A seven-year consecutive study of tourist satisfaction concluded that Western tourists are more satisfied than their Eastern counterparts with both tourism services and the destination of Hong Kong as a whole (Song \& Chon, 2015). Such a staisfaction descripancy is perhaps due to heterogenous tourist charaterics, manefisted in age, gender, income and other sociodemographic (Cha, McCleary, \& Uysal, 1995; Engs, Diebold, \& Hanson, 1996; Humara \& Sherman, 1999; Mattila et al., 2001; Saad, Gill, \& Nataraajan, 2005). In addtion, tourist typologies and travel activities undertaken at destinations may also affect customer satisfaction, along with their emotion and happiness (Bimonte \& Faralla, 2012; Gillet, Schmitz, \& Mitas, 2016; Neal, 2000). These studies imply that culture, along with sociodemographic and tourist behavioral patterns, can predict a broad range of tourist behavioral consequences, and thus warrants further empirical investigations.

While the effects of culture, sociodemographic, and travel patterns on tourist behavior have been examined in previous studies (Hudson \& Ritchie, 2001; Kastenholz, Carneiro, \& Eusébio, 2005; Pizam \& Jeong, 1996; Swanson \& Horridge, 2004), little is known about whether and how culture, sociodemographic, and travel patterns affect a set of behavioral consequences of hotel guests, such as perceived service quality, customer satisfaction and loyalty. An explanatory analysis in this regard might be difficult, as these variables were measured either at the ordinal or nominal level in survey-based studies. For instance, the ordinal measurement of income in many survey-based studies makes it difficult to detect the effect of income on structural relationships of latent variables. Little causality can be drawn between the covariates and the constructs when it comes to testing a group of covariates simultaneously. To reconcile the theoretical aspiration and methodological constraints, we develop a Multiple Indicators Multiple Causes (MIMIC) model to test the effects of these covariates on the behavioral consequences of hotel guests.

\section{LITERATURE REVIEW}

While previous research has addressed the effects of the covariates, such as sociodemographic, culture, and behavioral patterns on consumer behavior in different contexts, an integrated model 
is lacking that can synthesize the relationships between these covariates and consumer behavioral consequences. In what follows, we first review studies on consumer behavior outcomes in tourism and hospitality, and then those on the effects of these covariates on tourist behavior, both of which are used to justify the theoretical validity of the MIMIC model.

\subsection{Service Quality, Satisfaction, Loyalty, and Complaint Intentions}

Perceived service quality captures consumers' subjective judgment on general excellence or superiority of a product or service (Dhar, 2015; Parasuraman, Zeithaml, \& Berry, 1988; Zeithaml, 1987). In the hotel context, Oberoi and Hales (1990) suggested four key elements, namely facilities, pricing, activities, and catering, that can constitute customers' perceived service quality. Among the most widely cited conceptualizations of service quality is the SERVQUAL model, which has extensively been applied to study consumer behavior in tourism and hospitality (Parasuraman, Zeithaml, \& Berry, 1985, 1991; Wang et al., 2012). The applications covered a broad range of tourism and hospitality sectors, including hotels and lodging (Debasish \& Dey, 2015; Nikolaidis, Chrysikou, \& Alexandris, 2016), airlines (Liou et al., 2012; Wu \& Cheng, 2013), restaurants (Hansen, 2014; Tripathi \& Dave, 2014), and destination attractions (Frochot \& Hughes, 2000; Ryglová, Vajčnerová, \& Šácha, 2016). While these studies identified the antecedents and outcomes of perceived service quality, few have explored how demographics and culture affect hotel guests' perceived service quality.

The associations between service quality, customer satisfaction, customer loyalty, and complaint are well established in the marketing, tourism, and hospitality literature (Cole, Crompton, \& Willson, 2002; Kandampully \& Suhartanto, 2000; Ostrowski, O’Brien, \& Gordon, 1993). Despite being less challenging for companies to reach their loyal customers, acquiring new customers is still a priority as the incumbent customer base shrinks over time. Since acquiring a new customer is more costly than retaining an existing one (Peters, 1988), customer loyalty is essential to maintaining a long-term business success. Nurturing and corroborating customer loyalty entails a clear clarification of the building blocks of loyalty. Superior product and service quality as well as highly rated perceived value all lead to customer satisfaction and positive word-of-mouth communications (Moreira \& Silva, 2016), thereby enhancing customer loyalty (Cole et al., 2002; Kandampully \& Suhartanto, 2000) and dispelling customer complaints (Yu et al., 2014). Not only is customer satisfaction vital by itself, but it also has a mediating effect on the relationship between perceived service quality and customer loyalty (Caruana, 2002).

Consumer complaint behavior is defined as "an action taken by an individual which involves communicating something negative regarding a product or service either to the firm manufacturing or marketing that product or service or some third-party organizational entity" (Jacoby \& Jaccard, 1981, p. 6). To avoid, alleviate, and wisely respond to consumer complaints, researchers have devoted extensive attention to studying consumer complaints and remedy resolutions (Davidow, 2003; Karatepe, 2006; Knox \& van Oest, 2014). Notably, not all dissatisfied customers would complain publicly or in an active way that otherwise help firms address their complaints. Alternatively, consumers were found to simply ignore their dissatisfying experience or do nothing about it, while altering their future patronage or purchasing behavior (Rogers, Ross, \& Williams, 1992). 


\subsection{Cross-Cultural Analysis of Tourist Behavior}

Culture is instrumental in understanding tourist behavior, as certain behavioral responses change by consumers' cultural backgrounds (Kim \& Stepchenkova, 2016). A cultural approach to consumer behavior is anchored by the measure of cultural differences on five dimensions, namely power distance, individualism/collectivism, masculinity/femininity, uncertainty avoidance, and long-/short-term orientation (Hofstede, 2001; Hofstede \& Hofstede, 2005). Building upon the power distance of culture, Ngai et al. (2007) found that hotel guests from lower power-distance societies, such as Western countries, tend to voice their dissatisfaction and complain publicly while those from higher power-distance societies, such as Asian countries, are reluctant to do so when encountering dissatisfying services or experiences. American guests preferred directly complaining to hotel management or stopping patronage, while Japanese tended to take an indirect and passive approach with no further actions (Rogers et al., 1992). Due to the fear of "losing face," Asian guests would prefer private and low-profile ways of selfadvocating or not complain at all (Ngai et al., 2007).

Travel preference, particularly regarding traveling in a group or independently, are also affected by the dichotomy of individualism and collectivism impacts travel motivations (Maoz, 2007; Pizam \& Jeong, 1996). Tourists in highly individualistic culture behave more independently and egocentrically, and are more willing to distance from service providers (Sabiote-Ortiz, FríasJamilena, \& Castañeda-García, 2016). Since cross-cultural differences can also be manifested in risk taking behavior (Pizam \& Jeong, 1996), uncertainty avoidance affects tourist behavior through changing tourist's risk aversion and seeking thresholds (Litvin, Crotts, \& Hefner, 2004). In particular, the propensity to take risks affects tourist choices of travel activities. Tourists who have a tendency to take risks and seek sensations before and during their travel are more prone to engage in high-energy and outdoor activities (e.g., wilderness hiking and river rafting) and therefore prefer active and spontaneous vacations (Pizam \& Jeong, 1996). By contrast, those who are risk aversion would favor slow-paced and indoor activities (e.g., visiting friends and relatives and shopping) (Pizam \& Jeong, 1996).

Cultural backgrounds largely determine how people behave when being exposed to a new and unfamiliar culture. Different evaluations of destination, perceived service quality, satisfaction, and customer loyalty can be attributed to tourists' distinct cultural backgrounds or nationalities (Crotts \& Erdmann, 2000; Kim \& Stepchenkova, 2016; Sabiote-Ortiz et al., 2016; Wang, So, \& Sparks, 2017; Weiermair, 2000). For instance, tourists from Eastern cultures, such as Korea, emphasize harmony with nature and environment, while those from Western cultures value the local way of life and traditional attributes of destinations (Kim \& Stepchenkova, 2016). Also, consumers' expectations for, and perceptions of, service quality differ by the cultures they are being nurtured (Weiermair, 2000). This argument was evidenced by Laroche et al. (2004), who concluded that Japanese tend to rate superior services lower than their North American counterparts while are more prone to tolerate inferior services. Culture also exerts a moderating effect on the association between customer loyalty and corporate reputation (Duffy, 2003).

\subsection{Sociodemographic and Tourist Behavior}

Besides culture, a wide range of sociodemographic characteristics have been found to affect 
consumer motivations, attitudes, and perceptions (Humara \& Sherman, 1999; Keng, Richmond, \& Han, 1995; Saad et al., 2005). In tourism and hospitality settings, such characteristics as age, income, education, gender, and religion affect tourists' and hotel guests' motivations, desire to travel, expenditure, satisfaction, perceptions, and complaint intentions (Bernini \& Cracolici, 2015; Johns \& Gyimóthy, 2002; Lowyck, Langenhove, \& Bollaert, 1990; Ngai et al., 2007). Mattila et al. (2001) noted that gender and religious affiliations affected university students' destination choices as well as their expectations for the quality of hospitality services. Heung and Lam (2003) found that younger, well educated, and high-income hotel guests were prone to adopt vocal and active ways of complaining whereas older, less-educated, and lower-income guests preferred to voice their complaints privately and passively. Studies found that Japanese tourists behaved differently by age and educational background (Cha et al., 1995), while for Italians, age was negatively associated with their travel desire but positively associated with their expenditure (Bernini \& Cracolici, 2015).

Nevertheless, the effects of sociodemographic on hotel guests' behavior are underexplored in relation to the path analysis of behavioral latent variables, and little consensus on these effects is reached. Swanson and Horridge (2004) found no significant relationships between tourist souvenir shopping behavior and their demographics, including age, gender, income, education, and state of residence. While age affected customer loyalty and travel motivation in tourism (Bernini \& Cracolici, 2015; Hsu, 2000), it did not affect consumer preferences for hotel services (Lepsito \& McCleary, 1988). Chi (2011) concluded that customer satisfaction, customer loyalty, and perceptions of destination image do not vary by age and income. One plausible explanation is that destination-specific attributes moderate the effects of demographics on tourist behavior (Kastenholz et al., 2005; Swanson \& Horridge, 2004). Given the lack of consistency in explaining the effects of demographics on tourist behavior, more research on demographics and tourist behavior is required in different socio-cultural settings.

\subsection{Travel Patterns and Behavioral Consequences}

Travel patterns portray tourists' decision-making in three major travel subsectors: transportation, accommodation, and tourist attractions/activities (Becken, Simmons, \& Frampton, 2003; Oppermann, 1995). Since dining/catering is normally improvised at a destination, especially regarding international tourists choosing what restaurants and what meals at what dining time, it is hard to be factored into tourists' decision marking at the pre-travel stage. Different travel patterns can indicate different types of tourists, such as group/package tourists and independent/solo tourists (Bowie \& Chang, 2005). Group/package tourists' attitudes and expectations of package tours influenced their satisfaction with travel experience (Bowie \& Chang, 2005). Independent/solo travel has become increasingly popular among youths (LokerMurphy \& Pearce, 1995; Tsaur, Yen, \& Chen, 2010). When it comes to independent/solo travel, tourists plan travel itineraries by themselves and enjoy a higher degree of flexibility in travel itinerary than group tourists (Hyde \& Lawson, 2003; Tsaur et al., 2010). More importantly, what remains under investigated is whether and how group tourists and independent travelers could differ in terms of their perceived service quality, satisfaction, loyalty, and complaint intentions.

\section{CONCEPTUAL DEVELOPMENT}




\subsection{MIMIC Models in Consumer Behavior Research}

The Multiple Indicators Multiple Causes (MIMIC) model was developed to address latent variables that are measured by observable indicators while are affected by observable causes (Jöreskog \& Goldberger, 1975). Such models are featured by "a mixture of econometric and psychometric themes" (Jöreskog \& Goldberger, 1975). In some econometrics studies where a variable cannot be directly measured, the MIMIC modeling approach normally weighs in. For instance, Siegel (1997) treated price and quantity of computers as latent variables to reinvestigate the relationship between the use of computers and productivity, an approach contrasting to conventional direct measures of price and quality. Other examples included Rose and Spiegel (2011) using the MIMIC to model the severity of financial crisis, and Hassan \& Schneider (2016) modeling the shadow economy. In Maltritz et al.'s (2012) study, default risk of a country was modeled as a latent variable for the same of controlling for the measurement errors. Rahmana et al. (2011) modeled quality of life as a latent variable that links between observable causes and observable effects, by which the bias, inconsistency, and arbitrary weightings of explanatory factors can be reduced.

The use of the MIMIC in econometrics centers on dealing with unobservable variables, such as the severity of financial crisis and shadow economy, and thus entails specifying their observable indicators. In physiology and neurology where the MIMIC has been extensively applied though, rather than focusing on unobservable variables, the aim is to elicit the associations between various symptoms of a disease or mental disorder and individual patients' characteristics and specific clinical variables (Lim, 2015; Proitsi et al., 2011). In these studies, diseases such as dementia and psychopathy, on the one hand, are manifested in various symptoms, which can be measured directly, and on the other can be attributed to a wide range of individual characteristics possessed by patients (Lim, 2015; Proitsi et al., 2011). Applications of this sort in physiology and neurology have far-reaching implications for studying consumer behavior not least because many behavioral constructs are latent variables.

In many consumer behavior studies and tourist behavior studies in particular though, an analogy can be drawn to studies in physiology is that researchers almost always reported the profile of respondents on the one hand, while on the other tested a structural equation model without referring to whether and how these consumer characteristics in the profile may affect the structural relationships in the model or the indicators of the latent variables. That said, they treated consumer characteristics and the model separately, making no attempts to draw the associations between consumer characteristics and the indictors of latent variables. In this regard, the MIMIC is useful to unravel these associations between the covariates and the latent variables as well as between the covariates and the indictors that measure the latent variables. It follows that the latent variables function as mediators in path analysis, thus suggesting implications for directly managing the indictors while controlling for the effects of the latent variables.

\subsection{A MIMIC Model of Behavioral Consequences}

We develop a MIMIC model that blends the covariates that characterize and segment consumers with their behavioral consequences explained in orthodox consumer behavior frameworks (Chan et al., 2003; Fornell et al., 1996; Song et al., 2012). The MIMIC model consists of three 
components. The first component models the structural relationships between seven covariatesculture, gender, age, education, income, travel experience, and travel mode - and each of the four constructs of hotel guests' behavioral consequences, namely perceived service quality, satisfaction, loyalty, and complaint attentions. This component of the model is underpinned by our literature review aforementioned on cross-cultural behavior of consumers as well as the effects of sociodemographic and travel patterns on behavior consequences. This component aims to test whether the covariates can influence the structural relationships of the behavioral consequences, which represents the causal effects of the covariates. These causal effects suggest the heterogeneity of hotel guests' behavior that changes by these covariates. Specifically, we aim to examine whether service quality, customer satisfaction, customer loyalty, and complaint intentions vary by each of these covariates.

The second component models the relationships between each of the four constructs and their indicators, representing the measurement model. This component is underpinned by the literature review on the relationships between service quality, customer satisfaction, customer loyalty, and complaint intentions.

The mathematical expression of the MIMIC model is given as (Rose \& Spiegel, 2011):

$$
\begin{gathered}
y_{i, j}=\beta_{j} \xi_{i}+v_{i} \\
\xi_{i}=\gamma_{k} x_{i, k}+\zeta_{i}
\end{gathered}
$$

where $y_{i, j}$ is an observation of indicator $j$ of construct $i$, representing the measurement of the construct; $x_{i, k}$ is an observation of covariate $k$ that affects construct $i$, representing the cause of construct $i ; \xi_{i}$ is the behavioral consequence of hotel guests characterized by construct $i ; \beta$ and $\gamma$ are vectors of coefficients that need to be estimated, and $v$ and $\zeta$ are well-behaved disturbances.

In equation (1), we specify $\xi_{i}(i=4)$ as to include service quality, customer satisfaction, customer loyalty, and complaint intentions. In equation (2), we define $x_{i, k}(k=7)$ as to include culture, gender, age, education, income, travel experience, and travel mode. Given the baseline MIMIC model defined in equations (1) and (2), we outline the structural relationships between the four constructs that model behavioral consequences in the presence of the seven covariates. While some of these structural relationships have been tested valid in different contexts (Chan et al., 2003; Fornell, 1992; Song et al., 2012), they have not been examined when the effects of the covariates are factored into the analysis.

As an amendment to the baseline MIMIC model defined in equations (1) and (2), the third component specifies the direct associations between the covariates and the indictors of the latent variables of behavior consequences. These constructs thus become the mediators. This amendment has been widely used in medical research, aiming to uncover the associations between patients' attributes (covariates, such as sociodemographic) and observable clinical symptoms, while controlling for the effects of unobservable psychological and cognitive diseases 
or disorders (Gallo, Rabins, \& Anthony, 1999; Proitsi et al., 2011). These direct paths allow us to test the differences in the indicators of the constructs that can be explained by the covariates while holding the effects of the constructs constant (Gallo et al., 1999; Proitsi et al., 2011).

Figure 1 shows the MIMIC model, consisting of six hypotheses below for testing the structural relationships of the four constructs in the presence of the seven covariates.

H1: Service quality is positively associated with customer satisfaction.

$\mathrm{H} 2$ : Service quality is negatively associated with complaint intentions.

H3: Service quality is positively associated with customer loyalty.

H4: Customer satisfaction is positively associated with customer loyalty.

H5: Customer satisfaction is negatively associated with complaint intentions.

H6: Complaint intentions is negatively associated with customer loyalty.

We also propose 28 structural relationships to test the effects of the seven covariates on the four constructs of behavioral consequences. Drawing upon the literature, we hypothesize the associations that exist between each of the seven covariates and the four constructs, along the direct associations between the covariates and the indicators of the four constructs, ending up with a total of 70 structural relationships. For an illustration, Figure 1 also shows one of the associations between culture and one indicator of service quality.

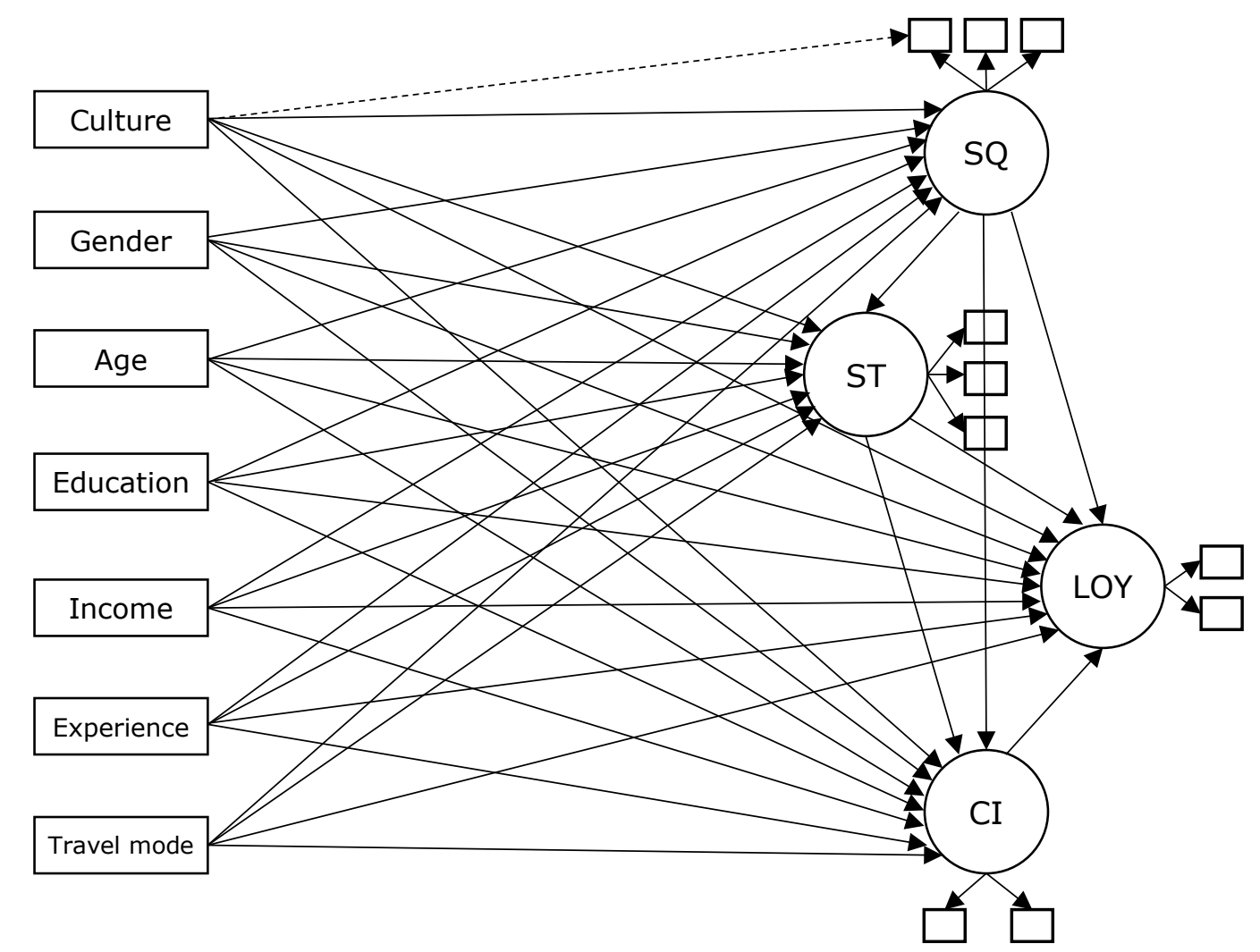

Notes: $\mathrm{SQ}=$ Service quality, $\mathrm{ST}=$ Customer satisfaction, $\mathrm{LOY}=$ Customer loyalty, and $\mathrm{CI}=$ Complaint intentions. The dashed path is one example in the model that illustrates the direct impact of a covariate on an indicator of a construct. 
Figure 1. A MIMIC model of behavioral consequences

\section{METHODS}

\subsection{Data}

The data were extracted from the Hong Kong tourist satisfaction annual survey (Song \& Chon, 2015). Data collection was conducted between 2010 and 2015 from Hong Kong's inbound tourists who stayed overnight at hotels during their trip in Hong Kong. Respondents were interviewed at major attraction locations and required to provide information about their experience at the most recent hotel they stayed during their travel in Hong Kong. We merged the datasets between 2010 and 2015 to generate a sufficient large sample to serve the study purposes. Although combining data collected in different time periods may cause problems of data inconsistency, using the combined dataset is an appropriate approach to analyzing such a complicated model in our study. The justifications for using similar merged dataset can be found in previous studies, especially when it comes to analyzing a model that requires a large crosssectional sample (e.g., Helliwell, Layard, \& Sachs, 2015). Finally, we obtained a sample of 2,267 valid responses to test the model.

\subsection{Variables and Measurement}

Table 1 shows the definitions and measurement of the variables. The seven covariates were measured at the nominal or ordinal level. Due to insufficient sample size for measuring each of the nationalities in our database, we grouped the nationalities of the respondents into two categories, namely Asian cultural backgrounds and non-Asian backgrounds. We used these two categories to approximate the measurement of culture, with " 1 " indicating hotel guests with Asian cultural backgrounds (Mainland China, Taiwan, Macau, Japan, and Korea) and " 0 " indicating their non-Asian counterparts (Americas, Europe, Africa, Middle East, Australia, New Zealand, and the Pacific). Similar classification was adopted by Ngai et al. (2007) in analyzing consumer complaint behavior of Asians and non-Asians about hotel services. Gender was measured at the nominal level, with " 1 " indicating males and " 0 ," females. Age, education, income and travel experience were measured at the ordinal level. Travel mode was measured at the nominal level, with " 1 " indicating hotel guests joining in group tours and " 0 " indicating those taking independent tours.

Table 1. Description of the variables

\begin{tabular}{lll}
\hline Variable & Description and measurement & Scale \\
\hline Covariates & & \\
Culture & Asian and non-Asian & Nominal \\
Gender & Female and male & Nominal \\
Age & Age intervals: $16-25,26-35,36-45,46-55,56-65$, and & Ordinal \\
& $66+$ years old & \\
Education & $\begin{array}{l}\text { Education levels: No formal education, } \\
\text { primary/elementary school, secondary/high school, }\end{array}$ & Ordinal \\
& college/university, and postgraduate & \\
Income intervals: Less than US $\$ 1,000 ;$ US $\$ 1,000-2,999 ;$ & Ordinal \\
& US $\$ 3,000-4,999 ;$ US $\$ 5,000-6,999 ;$ US $\$ 7,000-8,999 ;$ and & \\
& US $\$ 9,000$ or more & \\
\hline
\end{tabular}




\begin{tabular}{lll}
\hline Travel experience & $\begin{array}{l}\text { Travel frequency: Never, 1-3 times, 4-6 times, 7-9 times, } \\
\text { and } 10 \text { times or more }\end{array}$ & Ordinal \\
$\begin{array}{l}\text { Travel mode } \\
\text { Ponstructs }\end{array}$ & Nackage tour and independent tour & Ratio \\
Service quality & 11-point Likert scale from 0 to 10 & Ratio \\
Customer satisfaction & 11-point Likert scale from 0 to 10 & Ratio \\
Complaint intentions & 11-point Likert scale from 0 to 10 & Ratio \\
Customer loyalty & 11-point Likert scale from 0 to 10 & \\
\hline
\end{tabular}

Service quality was measured with three indicators, namely overall service performance of hotels perceived by guests, their judgment on the customization of hotel services, and their views on the reliability of service delivery (Bloemer, Ruyter, \& Wetzels, 1999; Song et al., 2012). Since multi-item scales are more reliable than single-item scales in measuring customer satisfaction (Conner \& Sparks, 1996; Fornell, 1992), guests' satisfaction with hotel services was measured with three indicators, namely their overall satisfaction with hotel services, their satisfaction with hotel services when compared with expectations, and their satisfaction with hotel services when compared with the most ideal situation that they could imagine (Chan et al., 2003; Song et al., 2012). Customer loyalty was measured with two indicators, namely guests' revisit intentions and their intention to recommend the hotel to others (Chan et al., 2003; Fornell et al., 1996; Song et al., 2012). Complaint intentions were measured by guests' intentions to complain about their unsatisfactory situations and experiences to employees and others (Song et al., 2012).

\subsection{Analysis}

We followed the procedure of analyzing the MIMIC model suggested by Proitsi et al. (2011). First, we performed a confirmatory factor analysis (CFA) on the ten indicators of the four constructs to verify the factor structure, followed by a discussion of the structural relationships between these four constructs. Second, by including the seven covariates, we transformed the structural equation model into the MIMIC model to test the effects of the covariates on the factor structure of hotel guests' behavioral consequences. Third, in the MIMIC model, we examined the direct associations between the covariates and the indicators of the constructs. This examination allows us to go beyond the construct-level analysis, which can help ground marketing and management policies on the observable indicators. The Maximum Likelihood (ML) estimation was used to estimate the model. Stata 14.1 was used to perform these analyses.

\section{RESULTS AND DISCUSSION}

\subsection{Descriptive Analysis}

Table 2 shows the profile of the respondents characterized by the seven covariates. Respondents from Asian cultures accounted for nearly $55 \%$ of the sample. Males were slightly more prevalent than females. More than half of the respondents aged between 16 and 35 years old. The respondents were well-educated, with more than $60 \%$ having obtained a college/university education. The income distribution was more or less equal on the five categories. As for respondents' travel experiences, $46 \%$ of the respondents were first-time visitors and $30 \%$ traveled between one to three times in Hong Kong. As for travel mode, a vast majority of the respondents were independent tourists $(84 \%)$. 
Table 2. Description of the covariates

\begin{tabular}{|c|c|c|c|c|c|}
\hline Covariates & $N$ & $\%$ & Covariates & $N$ & $\%$ \\
\hline Culture & & & Education (continued) & & \\
\hline Asian cultures & 1,239 & 54.7 & Postgraduate & 477 & 21.0 \\
\hline Non-Asian cultures & 1,028 & 45.3 & Income & & \\
\hline Gender & & & Less than US $\$ 1,000$ & 215 & 9.5 \\
\hline Female & 1,092 & 48.2 & US\$1,000-2,999 & 575 & 25.4 \\
\hline Male & 1,175 & 51.8 & US $\$ 3,000-4,999$ & 455 & 20.1 \\
\hline Age & & & US $\$ 5,000-6,999$ & 334 & 14.7 \\
\hline $16-25$ & 466 & 20.6 & US\$7,000-8,999 & 246 & 10.9 \\
\hline $26-35$ & 738 & 32.6 & US $\$ 9,000$ or more & 442 & 19.5 \\
\hline $36-45$ & 444 & 19.6 & Travel experience & & \\
\hline $46-55$ & 362 & 16.0 & Never & 1,043 & 46.0 \\
\hline $56-65$ & 190 & 8.4 & $1-3$ times & 679 & 30.0 \\
\hline $66+$ & 67 & 3.0 & $4-6$ times & 232 & 10.2 \\
\hline Education & & & 7-9 times & 67 & 3.0 \\
\hline No formal education & 11 & .5 & 10 times or more & 246 & 10.9 \\
\hline Primary/elementary school & 20 & .9 & Travel mode & & \\
\hline Secondary/high school & 326 & 14.4 & Independent tours & 1,905 & 84.0 \\
\hline College/university & 1,431 & 63.1 & Package tours & 362 & 16.0 \\
\hline
\end{tabular}

Notes: Asian cultures included Mainland China (21.8\%), Taiwan and Macau (15.0\%), and Japan and Korea (17.9\%). Non-Asian cultures included Americas (14.6\%), Australia, New Zealand, and the Pacific (12.4\%), Europe (16.1\%), Africa (1.3\%), and the Middle East (1.0\%).

\subsection{Structural Equation Model}

We performed a CFA to verify the factor structure of the four constructs (Tables 3 and 4). The results show that the measurement model had satisfactory goodness of fit $\left(\chi^{2}=112.93, d f=28, p\right.$ $=.000, \mathrm{RMSEA}=.037, \mathrm{CFI}=.997$, and TLI $=.995)$. All factor loadings of the four constructs were above .80 and statistically significant at $p<.001$ (Table 3). The Modification Indices (MI) did not show any evidence for the cross-loadings of the indicators on the constructs. All four constructs were highly correlated (Table 4), and the signs of the correlations were consistent with the theories (Kozak \& Rimmington, 1999; Song et al., 2012; Yoon \& Uysal, 2005). Table 5 shows the structural model of hotel guests' behavioral consequences. The structural model also achieved satisfactory goodness of fit, with the key goodness-of-fit indices meeting the criteria $\left(\chi^{2}\right.$ $=171.80, d f=29, p=.000, \mathrm{RMSEA}=.056, \mathrm{CFI}=.980$, and TLI $=.968)$. We verified five out of the total six structural relationships in the model (Table 5).

Table 3. Measurement model

\begin{tabular}{lccccc}
\hline Construct & Factor loadings & S.E. & $z$ & $p>|z|$ & {$[95 \%$ Conf. Interval] } \\
\hline Service quality & & & & & \\
Overall performance & $\mathbf{. 9 6 3}^{* * *}$ & .003 & 323.420 & .000 & {$[.957, .969]$} \\
Customizations & $\mathbf{. 9 4 1}^{\text {****}}$ & .003 & 296.090 & .000 & {$[.935, .947]$} \\
Reliability & $\mathbf{. 9 5 4}^{* * *}$ & .003 & 296.500 & .000 & {$[.948, .961]$} \\
Customer satisfaction & & & & & \\
Overall satisfaction & $\mathbf{. 8 9 5}^{* * *}$ & .005 & 175.910 & .000 & {$[.885, .905]$} \\
Comparison with expectations & $\mathbf{. 8 3 1}^{\text {****}}$ & .007 & 114.460 & .000 & {$[.817, .845]$} \\
Comparison with ideal & $\mathbf{. 9 1 4}^{* * *}$ & .005 & 201.810 & .000 & {$[.905, .923]$} \\
Complaint intentions & & & & & \\
Complain to employees & $\mathbf{. 8 5 6}^{* * *}$ & .011 & 74.880 & .000 & {$[.833, .878]$} \\
Complain to others & $\mathbf{. 9 8 0}^{* * *}$ & .011 & 85.770 & .000 & {$[.958,1.003]$} \\
Customer loyalty & & & & &
\end{tabular}




\begin{tabular}{llllll} 
Revisit intentions & $\mathbf{. 9 2 0}^{\text {****}}$ & .004 & 206.340 & .000 & {$[.911, .928]$} \\
Recommendation to others & $\mathbf{. 9 7 5}^{\text {*** }}$ & .003 & 286.100 & .000 & {$[.968, .981]$} \\
\hline
\end{tabular}

Notes: $\chi^{2}=112.93, d f=28, p=.000, \mathrm{RMSEA}=.037, \mathrm{CFI}=.997$, and TLI $=.995$.

${ }^{*} p<.05,{ }^{* *} p<.01,{ }^{* * *} p<.001$.

Table 4. Covariance of the constructs

\begin{tabular}{lrrrrr}
\hline Construct & $b$ & $S . E$. & $z$ & $p>|z|$ & {$[95 \%$ Conf. Interval] } \\
\hline Cov (SQ, ST) & $\mathbf{. 9 0 4}^{* * * *}$ & .005 & 169.220 & .000 & {$[.893, .914]$} \\
Cov (SQ, LOY) & $\mathbf{. 8 2 0}^{* * *}$ & .008 & 104.640 & .000 & {$[.805, .836]$} \\
Cov (SQ, CI) & $\mathbf{. . 5 0 0}^{* * *}$ & .017 & -29.300 & .000 & {$[-.534,-.467]$} \\
Cov (ST, LOY) & $\mathbf{. 8 6 2}^{* * * *}$ & .007 & 121.580 & .000 & {$[.849, .876]$} \\
Cov (ST, CI) & $\mathbf{- . 4 8 0}^{* * *}$ & .018 & -26.770 & .000 & {$[-.515,-.445]$} \\
Cov (LOY, CI) & $\mathbf{- . 4 4 6}^{* * *}$ & .018 & -24.660 & .000 & {$[-.481,-.411]$} \\
\hline
\end{tabular}

Notes: $\chi^{2}=112.93, d f=28, p=.000, \mathrm{RMSEA}=.037, \mathrm{CFI}=.997$, and TLI $=.995$.

$\mathrm{SQ}=$ Service quality, $\mathrm{ST}=$ Customer satisfaction, $\mathrm{CI}=$ Complaint intentions, and LOY $=$ Customer loyalty.

${ }^{*} p<.05,{ }^{* *} p<.01,{ }^{* * *} p<.001$.

Table 5. Structural model

\begin{tabular}{llrrrrr}
\hline Dependent & Independent & $b$ & S.E. & $z$ & $p>|z|$ & [95\% Conf. Interval] \\
\hline ST & SQ & $\mathbf{. 9 0 9}^{* * * *}$ & .005 & 173.770 & .000 & {$[.899, .919]$} \\
CI & ST & $\mathbf{. . 1 2 9 *}^{*}$ & .058 & -2.210 & .027 & {$[-.243,-.015]$} \\
& SQ & $\mathbf{. . 3 8 6}^{* * *}$ & .058 & -6.710 & .000 & {$[-.499,-.273]$} \\
& ST & $\mathbf{. 6 4 4}^{* * * *}$ & .037 & 17.160 & .000 & {$[.570, .717]$} \\
& CI & -.022 & .014 & -1.540 & .124 & {$[-.050, .006]$} \\
& SQ & $\mathbf{. 2 2 9}^{* * *}$ & .038 & 5.990 & .000 & {$[.154, .304]$} \\
\hline
\end{tabular}

Notes: $\chi^{2}=171.80, d f=29, p=.000$, RMSEA $=.056, \mathrm{CFI}=.980$, and TLI $=.968$.

$\mathrm{SQ}=$ Service quality, $\mathrm{ST}=$ Customer satisfaction, $\mathrm{CI}=$ Complaint intentions, and LOY $=$ Customer loyalty.

${ }^{*} p<.05,{ }^{* *} p<.01,{ }^{* * *} p<.001$.

\subsection{The MIMIC Model}

We incorporated the seven covariates in the MIMIC structural model to test the effects of these covariates on the four-factor structural equation model. Table 6 shows that the MIMIC model had a good model fit $\left(\chi^{2}=303.33, d f=71, p=.000\right.$, RMSEA $=.056, \mathrm{CFI}=.980$, and TLI $=.968)$. We found that five hypotheses of the structural relationships were supported in the presence of the seven covariates. Service quality had a positive effect on customer satisfaction, and also this effect was the largest among others $(\beta=.906, p<.001)$, supporting hypothesis H1. Service quality also had a positive effect on customer loyalty $(\beta=.224, p<.001)$, which supports hypothesis $\mathrm{H} 3$, and, as expected, a negative effect on complaint intentions $(\beta=-.384, p$ $<.001$ ), supporting hypothesis H2. Customer satisfaction had a positive effect on customer loyalty $(\beta=.650, p<.001)$, which supports hypothesis $\mathrm{H} 4$, and, as expected, a negative effect on complaint intentions $(\beta=-.119, p<.05)$, supporting hypothesis H5. No evidence was found for the negative association between complaint intentions and customer loyalty (H6).

Table 6. MIMIC model

\begin{tabular}{llrrrrr}
\hline Dependent & Independent & $\beta$ & S.E. & $z$ & $p>|z|$ & {$[95 \%$ Conf. Interval] } \\
\hline Service quality & Culture & $\mathbf{. . 1 2 0}^{* * *}$ & .024 & -5.060 & .000 & {$[-.167,-.074]$} \\
& Gender & $\mathbf{. . 0 7 0}^{* *}$ & .021 & -3.250 & .001 & {$[-.112,-.028]$} \\
& Age & $\mathbf{. 0 5 1}^{*}$ & .023 & 2.210 & .027 & {$[.006, .097]$} \\
& Education & .015 & .022 & .700 & .481 & {$[-.027, .057]$} \\
& Income & $\mathbf{. 0 5 7}^{*}$ & .024 & 2.370 & .018 & {$[.010, .104]$}
\end{tabular}




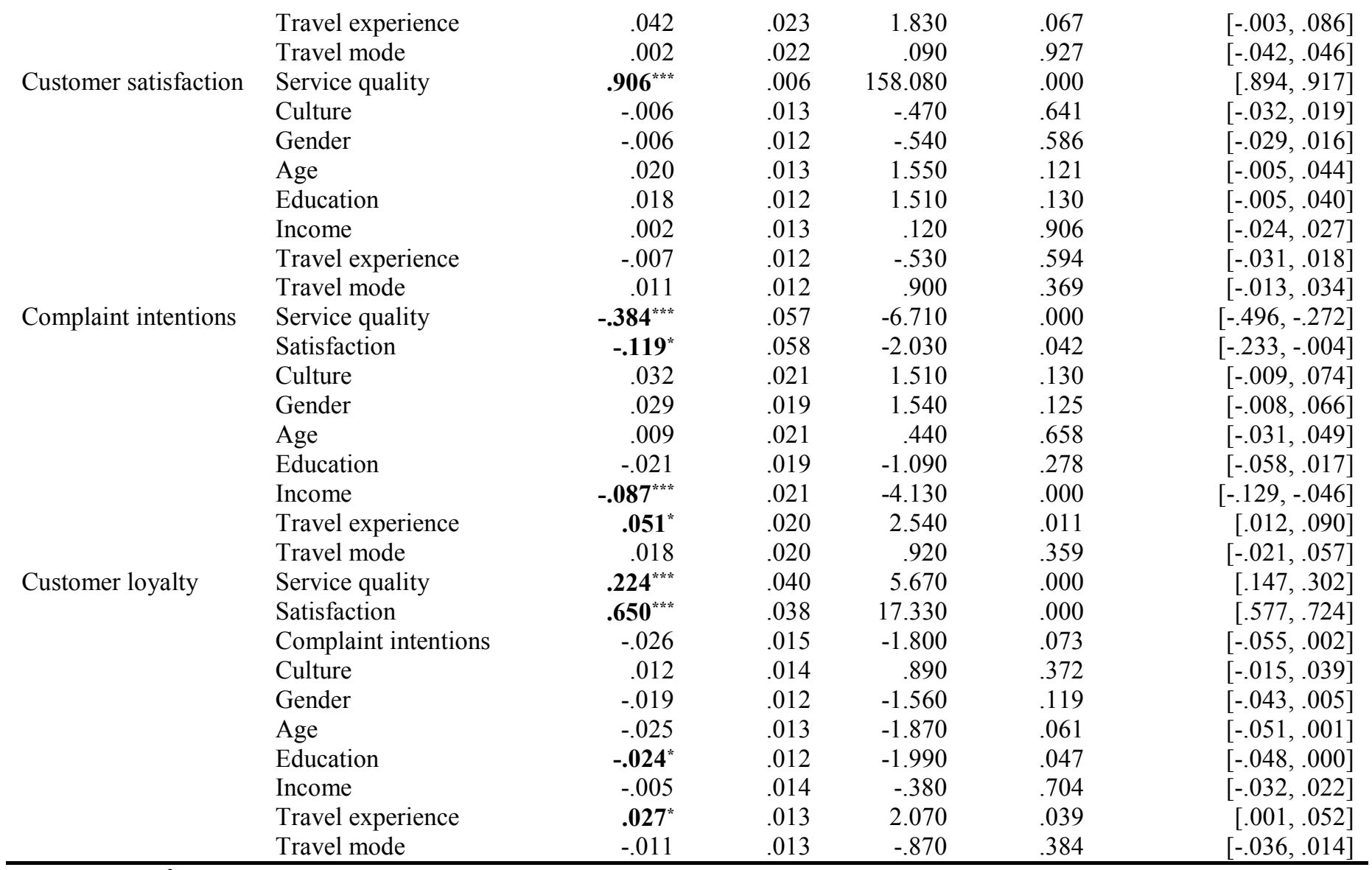

Notes: $\chi^{2}=303.33, d f=71, p=.000, \mathrm{RMSEA}=.056, \mathrm{CFI}=.980$, and TLI $=.968$.

${ }^{*} p<.05,{ }^{* *} p<.01,{ }^{* * *} p<.001$.

Table 6 also shows the path coefficients for the effects of the seven covariates on the four constructs. Culture and most of the demographic variables were the significant predictors of service quality. The effect of culture on service quality suggests that hotel non-Asian guests (including Americas, Australia, New Zealand, and Europe) tend to rate service quality higher than their Asian counterparts (Mainland China, Taiwan, Macau, Japan, and Korea) $(\beta=-.120, p$ $<.001)$. Although the effect of gender on service quality was small, females tended to rate service quality higher than males $(\beta=-.070, p<.01)$. The effect of age on hotel guests' perception of service quality was positive, suggesting that the elderly tend to rate service quality higher than younger guests $(\beta=.051, p<.05)$. We found that income had a positive yet small effect on hotel guests' rate of service quality $(\beta=.057, p<.05)$. Wealthier guests tended to rate service quality higher. No evidence was found for the effects of the covariates on the satisfaction of hotel guests, perhaps because the substantially high correlation between service quality and customer satisfaction suppressed these effects.

\subsection{Direct Effects of Covariates on Construct Indicators}

Based on the verified MIMIC model, we used a stepwise forward method (Proitsi et al., 2011) to add one direct path each time that links each of the seven covariates to each of the indicators of the constructs, which allowed us to test the direct associations between the covariates and the 
indicators. Table 7 shows the $\chi^{2}$ values of the 70 structural equation models, along with their model fit indices $(\mathrm{RMSEA}=.056, \mathrm{CFI}=.980$, and TLI $=.968)$. We compared the $\chi^{2}$ values of each of these 70 models and the baseline MIMIC model that specified no direct paths between the covariates and the indicators to assess whether the model fit was improved.

Table 7. Chi-square statistics of the MIMIC models

\begin{tabular}{|c|c|c|c|c|c|c|c|}
\hline Item & Culture & Gender & Age & Education & Income & $\begin{array}{r}\text { Travel } \\
\text { experience }\end{array}$ & $\begin{array}{c}\text { Travel } \\
\text { mode }\end{array}$ \\
\hline \multicolumn{8}{|l|}{ Service quality } \\
\hline Overall performance & 292.43 & 303.33 & 302.85 & 303.07 & 303.24 & 301.74 & 303.27 \\
\hline Customizations & 302.26 & 303.06 & 303.27 & 303.30 & 303.06 & 303.07 & 302.82 \\
\hline Reliability & 297.77 & 303.10 & 303.11 & 303.21 & 303.20 & 302.73 & 302.29 \\
\hline \multicolumn{8}{|l|}{ Customer satisfaction } \\
\hline Overall satisfaction & 299.02 & 302.54 & 289.05 & 284.53 & 302.88 & 300.31 & 302.24 \\
\hline Comparison with expectations & 298.03 & 302.32 & 302.50 & 292.26 & 292.95 & 303.16 & 298.96 \\
\hline Comparison with ideal & 288.58 & 303.33 & 294.86 & 301.00 & 299.59 & 299.31 & 296.17 \\
\hline \multicolumn{8}{|l|}{ Complaint intentions } \\
\hline Complain to employees & 296.40 & 302.40 & 302.93 & 302.20 & 303.32 & 301.44 & 295.48 \\
\hline Complain to others & 296.40 & 302.40 & 302.93 & 302.20 & 303.32 & 301.44 & 295.48 \\
\hline \multicolumn{8}{|l|}{ Customer loyalty } \\
\hline Revisit intentions & 289.32 & 303.32 & 298.66 & 303.24 & 297.24 & 294.78 & 301.78 \\
\hline Recommendation to others & 289.32 & 303.32 & 298.66 & 303.24 & 297.24 & 294.78 & 301.78 \\
\hline
\end{tabular}

Notes: All 70 MIMIC models had the model fit indices: RMSEA $=.056$, CFI $=.980$, and TLI $=.968$.

Chi-square statistics higher than that of the baseline MIMIC model are highlighted in bold.

We found that the $\chi^{2}$ values decreased for MIMIC models that specified the direct paths between three covariates (culture, education, and travel mode) and the indicators of the constructs, suggesting that model fit was improved compared to the baseline MIMIC model. For the culture covariate, model fit was increased for the six models that specified the direct paths between culture and all three indicators of service quality, between culture and both indicators of customer loyalty, and between culture and one indicator of customer satisfaction. For the education covariate, model fit was improved for two models that specified the direct paths between education and two indicators of customer satisfaction. For travel mode, model fit was improved for two models that specified the direct paths between travel model and both indicators of complaint intentions.

In the MIMIC model with the constructs being controlled, we were able to assess the direct effects of the covariates on the indicators of the constructs. Table 8 shows that all six covariates explained the variances in the indicators of the four constructs while holding the effects of the corresponding constructs constant. This result suggests that hotel guests' behavioral consequences characterized by these four constructs are heterogeneous and vary across the covariates. In particular, after controlling for the effect of customer satisfaction, all the three indicators of customer satisfaction were affected by the six covariates, indicating that different dimensions of hotel guests' satisfaction differ by culture, age, education, and so on, despite no difference detected at the construct level. For instance, Table 8 shows that non-Asian guests rated their "overall satisfaction with hotel services" $(\beta=-.024, p<.05)$ and "comparison with their expectations of hotel services" $(\beta=-.030, p<.05)$ higher than their Asian counterparts, who though rated "comparison with the ideal hotel services" higher $(\beta=.045, p<.001)$. 
Table 8. Direct effects of covariates on construct indicators

\begin{tabular}{|c|c|c|c|c|c|c|c|}
\hline Item & Culture & Gender & Age & Education & Income & $\begin{array}{r}\text { Travel } \\
\text { experience }\end{array}$ & $\begin{array}{c}\text { Travel } \\
\text { mode }\end{array}$ \\
\hline \multicolumn{8}{|l|}{ Service quality } \\
\hline Overall performance & $\begin{array}{l}\mathbf{. 0 2 7} 7^{* *} \\
(.008)\end{array}$ & $\begin{array}{c}-.001 \\
(.008)\end{array}$ & $\begin{array}{r}.006 \\
(.008)\end{array}$ & $\begin{array}{r}-.004 \\
(.008)\end{array}$ & $\begin{array}{c}-.002 \\
(.008)\end{array}$ & $\begin{array}{r}0.010 \\
(.008)\end{array}$ & $\begin{array}{r}.002 \\
(.008)\end{array}$ \\
\hline Customizations & $\begin{array}{l}-.008 \\
(.008)\end{array}$ & $\begin{array}{r}.004 \\
(.008)\end{array}$ & $\begin{array}{r}-.002 \\
(.008)\end{array}$ & $\begin{array}{r}.001 \\
(.008)\end{array}$ & $\begin{array}{r}.004 \\
(.008)\end{array}$ & $\begin{array}{r}-.004 \\
(.008)\end{array}$ & $\begin{array}{l}.006 \\
(.008)\end{array}$ \\
\hline Reliability & $\begin{array}{l}-.020^{*} \\
(.009)\end{array}$ & $\begin{array}{r}-.004 \\
(.008)\end{array}$ & $\begin{array}{r}-.004 \\
(.009)\end{array}$ & $\begin{array}{r}.003 \\
(.008)\end{array}$ & $\begin{array}{r}-.002 \\
(.009)\end{array}$ & $\begin{array}{r}-.007 \\
(.008)\end{array}$ & $\begin{array}{r}-.009 \\
(.008)\end{array}$ \\
\hline \multicolumn{8}{|l|}{ Customer satisfaction } \\
\hline Overall satisfaction & $\begin{array}{l}-.024^{*} \\
(.012)\end{array}$ & $\begin{array}{r}-0.010 \\
(.012)\end{array}$ & $\begin{array}{r}-.044^{* * * *} \\
(.012)\end{array}$ & $\begin{array}{c}. \mathbf{0 5 0}^{* * * *} \\
(.012)\end{array}$ & $\begin{array}{r}-.008 \\
(.012)\end{array}$ & $\begin{array}{r}-0.02 \\
(.012)\end{array}$ & $\begin{array}{r}-.012 \\
(.012)\end{array}$ \\
\hline Comparison with expectations & $\begin{array}{l}-.030^{*} \\
(.013)\end{array}$ & $\begin{array}{r}.013 \\
(.013)\end{array}$ & $\begin{array}{r}.012 \\
(.013)\end{array}$ & $\begin{array}{r}-.043^{* * *} \\
(.013)\end{array}$ & $\begin{array}{l}.042^{* * *} \\
(.013)\end{array}$ & $\begin{array}{l}-.005 \\
(.013)\end{array}$ & $\begin{array}{l}-.027^{*} \\
(.013)\end{array}$ \\
\hline Comparison with ideal & $\begin{array}{r}\mathbf{. 0 4 5}^{\text {*** }} \\
(.012)\end{array}$ & $\begin{array}{r}.001 \\
(.011)\end{array}$ & $\begin{array}{l}. \mathbf{0 3 4} 4^{* *} \\
(.011)\end{array}$ & $\begin{array}{c}-.018 \\
(.012)\end{array}$ & $\begin{array}{r}-.022 \\
(.012)\end{array}$ & $\begin{array}{l}. \mathbf{0 2 3}^{*} \\
(.011)\end{array}$ & $\begin{array}{l}. \mathbf{. 0 3 1}^{* * *} \\
(.011)\end{array}$ \\
\hline \multicolumn{8}{|l|}{ Complaint intentions } \\
\hline Complain to employees & $\begin{array}{l}\mathbf{. 0 3 1}^{* *} \\
(.012)\end{array}$ & $\begin{array}{r}-.011 \\
(.012)\end{array}$ & $\begin{array}{r}.007 \\
(.012)\end{array}$ & $\begin{array}{c}-.012 \\
(.012)\end{array}$ & $\begin{array}{r}-.001 \\
(.012)\end{array}$ & $\begin{array}{r}.016 \\
(.011)\end{array}$ & $\begin{array}{l}\mathbf{. 0 3 2}^{* *} \\
(.011)\end{array}$ \\
\hline Complain to others & $\begin{array}{l}-.036^{*} \\
(.014)\end{array}$ & $\begin{array}{r}.013 \\
(.013)\end{array}$ & $\begin{array}{r}-.008 \\
(.013)\end{array}$ & $\begin{array}{r}.014 \\
(.013)\end{array}$ & $\begin{array}{r}.001 \\
(.014)\end{array}$ & $\begin{array}{l}-.018 \\
(.013)\end{array}$ & $\begin{array}{r}-.037^{* * *} \\
(.013)\end{array}$ \\
\hline \multicolumn{8}{|l|}{ Customer loyalty } \\
\hline Revisit intentions & $\begin{array}{r}\mathbf{. 0 3 5}^{\text {****}} \\
(.009)\end{array}$ & $\begin{array}{r}.001 \\
(.009)\end{array}$ & $\begin{array}{c}. \mathbf{0 2 0} \\
(.009)\end{array}$ & $\begin{array}{r}.003 \\
(.009)\end{array}$ & $\begin{array}{l}-.023 \\
(.009)\end{array}$ & $\begin{array}{l}.027^{* *} \\
(.009)\end{array}$ & $\begin{array}{r}.012 \\
(.009)\end{array}$ \\
\hline Recommendation to others & $\begin{array}{r}-.037^{* * * *} \\
(.010)\end{array}$ & $\begin{array}{r}-.001 \\
(.010)\end{array}$ & $\begin{array}{l}-.022^{*} \\
(.010)\end{array}$ & $\begin{array}{r}-.003 \\
(.010)\end{array}$ & $\begin{array}{c}. \mathbf{0 2 5} \\
(.010)\end{array}$ & $\begin{array}{r}-.029^{* * *} \\
(.010)\end{array}$ & $\begin{array}{l}-.012 \\
(.010)\end{array}$ \\
\hline
\end{tabular}

Notes: Standard deviations are in parentheses

${ }^{*} p<.05,{ }^{* *} p<.01,{ }^{* * *} p<.001$.

After controlling for the effects of customer loyalty, we found that the two indicators of customer loyalty were affected by four covariates, namely culture, age, income, and travel experience. Take age for example. Table 8 shows that younger guests tended to recommend their hotels to others $(\beta=-.022, p<.05)$ while the elderly wanted to stay at the same hotel in the future $(\beta$ $=.020, p<.05$ ). The two indicators of complaint intentions were affected by culture and travel mode. After controlling for the effects of complaint intentions, Asian hotel guests tended to complain to employees $(\beta=.031, p<.01)$ while their non-Asian counterparts tended to complain to others $(\beta=-.036, p<.05)$. Our result deviated from Huang et al. (1996), who found that American guests preferred to complain directly to hotel management while Japanese tended to complain indirectly or passively. After controlling for the effects of service quality, Asian guests rated overall service performance of hotels higher $(\beta=.027, p<.01)$ while their non-Asian counterparts rated the reliability of service performance higher $(\beta=-.020, p<.05)$.

\section{CONCLUSION}

\subsection{Theoretical Implications}

We have extended consumer behavior research in tourism and hospitality in two ways. First, we highlighted the heterogeneity of hotel guests in examining their perception of service quality, customer satisfaction, customer loyalty, and complaint intentions. We verified the heterogeneity of hotel guests' behavior, which varies by culture, sociodemographic, and travel patterns (Ayeh, 
Au, \& Law, 2016; Birinci, Berezina, \& Cobanoglu, 2018; Masiero, Pan, \& Heo, 2016; NúñezSerrano, Turrión, \& Velázquez, 2014). Second, some studies have shown that consumer and tourist behavior would change by sociodemographic, yet the analyses in those studies were relatively exploratory (Kastenholz et al., 2005; Swanson \& Horridge, 2004). By developing the MIMIC model, we extended previous research, which focused on the associations between covariates and tourist behavior, to look into a set of causes of consumer behavioral consequences that were explained by the seven covariates in the hotel context.

Having included the seven covariates, we verified the four-factor structure of hotel guests' behavioral consequences. These results are consistent with studies concluding that customer satisfaction and loyalty are the consequences of service quality (Kozak \& Rimmington, 1999; Song et al., 2012; Yoon \& Uysal, 2005). Notably, the MIMIC model has verified the effects of the seven covariates on the structural relationships of the four constructs. We found that culture played a significant role in affecting hotel guests' perception of service quality, and specifically non-Asian guests rated service quality higher than their Asian counterparts. A plausible explanation grounded in customer satisfaction and happiness research (Laroche et al., 2004) states that people in Western cultures are happier than their counterparts in Eastern cultures (Hampton \& Marshall, 2000; Kang et al., 2003; Suh et al., 1998). Therefore, consumers' perception of service quality may not be fully accounted for by a service itself, but perhaps depends on consumers' inherent attributes that are rooted in their cultural background.

As for sociodemographic, gender matters to consumers' perception of service quality, and specifically, females rated service quality higher than males. This is perhaps because females tend to tolerate low-quality services, ending up with a positive view on service delivery. Similarly, the elderly rated service quality higher than young guests as their travel experience increased over time, indicating that travel experience may increase the tolerance level of guests. Since high-income guests tend to stay in upscale hotels that provide them with high-quality services, not surprisingly we found the positive effect of income on hotel guests' perception of service quality. For the same token, we found that high-income guests complained less about hotel services, suggesting that their perceived service quality and customer satisfaction would be high. Interestingly, well-educated guests were less loyal to the hotels they usually stay, suggesting that customer loyalty fades with educational attainment. Since well-educated guests can easily access information related to their hotels as well as possess sufficient information of alternative hotels, switching to alternative hotels is easy, and they eventually become less loyal to certain hotels even though they are satisfied with the services.

\subsection{Practical Implications}

The practical implications of this study lie with the direct associations between the covariates and the indicators of the constructs. After controlling for the effects of the constructs, we found that six covariates explained the variances in the construct indicators. Since the indicators like the covariates are observable, they can be seen as diagnosis indicators of service performance, suggesting directions for hotel management to address areas that hotels need to improve to increase customer satisfaction. The covariates, on the other hand, can be used to identify the market segments, for which tailed marketing policies and strategies can be carried out. Thus, management and marketing strategies, which used to be performed on the construct level, can be 
shifted to the indicator level, making these strategies manageable in hotel operation. These indicator-based policies have long been overlooked in SEM-based consumer behavior research, where indicators simply served for a measurement purpose, not for a management tool.

To illustrate the idea of the indicator-based management tool, one example is the direct associations between culture and the indicators of customer satisfaction. Since non-Asian guests are more satisfied with hotel services when service performance meets their expectations, hotel managers should focus on understanding the expectations of these guests and direct resources to alter their expectations, and thereby increasing their satisfaction. However, Asian guests tend to conceive a scenario, in which all aspects of service performance are perfect and use this ideal situation as a benchmark for evaluating the hotel services they encountered. They tend to be more satisfied when their experienced services match with the conceived scenario. To better develop and implement marketing strategies, hotel managers should better understand the heterogeneity of consumer behavior that is manifested at the indicator-level.

\subsection{Limitations and Future Research}

This study has two limitations in relation to the data treatment. First, to obtain a sufficiently large sample size to test the effects of the covariates, we combined the data collected annually from 2010 to 2015. Consumer behavior may change over time, but the change was neither addressed in our study nor captured by the model. Second, to test the effect of culture on hotel guests' behavior, we classified the guest respondents into two cultural groups, Asian culture, and nonAsian culture. While this classification may account for some group differences rooted in culture, each group was still culturally heterogeneous by nationality. This heterogeneity may impede us from capturing the subtle differences pertinent to different nationalities. For instance, in the nonAsian group, Europe, Africa, and the Middle East and Africa are by no means culturally similar. In the Asian group, Chinese culture is arguably different from Japanese and Korean cultures despite their close kinships, but we did not differentiate between them.

Future research should look into sub-cultural differences by determining hotel guests' behavioral consequences that may change by their nationalities, instead of simply distinguishing between Asian and non-Asian cultures. More importantly, due to the accelerating internationalization of global consumers, it becomes commonplace that a tourist born in one country receives education and/or works in other countries, thereby exposed to multiple cultures. Hotel guests' behavior should thus be examined with reference to the cultural interactions between their birthplace and countries where they live or work. We also recommend future studies employ the MIMIC model in various socioeconomic circumstances to further validate its validity and applicability. 


\section{REFERENCES}

Anderson, E. W., \& Fornell, C. (2000). Foundations of the American customer satisfaction index. Total Quality Management, 11(7), 869-882.

Ayeh, J. K., Au, N., \& Law, R. (2016). Investigating cross-national heterogeneity in the adoption of online hotel reviews. International Journal of Hospitality Management, 55, 142-153.

Becken, S., Simmons, D., \& Frampton, C. (2003). Segmenting tourists by their travel pattern for insights into achieving energy efficiency. Journal of Travel Research, 42(1), 48-56.

Bernini, C., \& Cracolici, M. F. (2015). Demographic change, tourism expenditure and life cycle behaviour. Tourism Management, 47, 191-205.

Bimonte, S., \& Faralla, V. (2012). Tourist types and happiness a comparative study in Maremma, Italy. Annals of Tourism Research, 39(4), 1929-1950.

Birinci, H., Berezina, K., \& Cobanoglu, C. (2018). Comparing customer perceptions of hotel and peer-to-peer accommodation advantages and disadvantages. International Journal of Contemporary Hospitality Management, 30(2), 1190-1210.

Bloemer, J., Ruyter, K. D, \& Wetzels, M. (1999). Linking perceived service quality and service loyalty: A multi-dimensional perspective. European Journal of Marketing, 33(11/12), $1082-1106$.

Bowie, D., \& Chang, J. C. (2005). Tourist satisfaction: A view from a mixed international guided package tour. Journal of Vacation Marketing, 11(4), 303-322.

Caruana, A. (2002). Service loyalty: The effects of service quality and the mediating role of customer satisfaction. European Journal of Marketing, 36(7/8), 811-828.

Cha, S., McCleary, K. W., \& Uysal, M. (1995). Travel motivations of Japanese overseas travelers: A factor-cluster segmentation approach. Journal of Travel Research, 34(1), 3339.

Chan, L. K., Hui, Y. V., Lo, H. P., Tse, S. K., Tso, G. K., \& Wu, M. L. (2003). Consumer satisfaction index: New practice and findings. European Journal of Marketing, 37(5/6), 872-909.

Chen, C. M., Chen, S. H., \& Lee, H. T. (2011). The destination competitiveness of Kinmen's tourism industry: Exploring the interrelationships between tourist perceptions, service performance, customer satisfaction and sustainable tourism. Journal of Sustainable Tourism, 19(2), 247-264.

Chi, C. G. Q. (2011). Destination loyalty formation and travelers' demographic characteristics: A multiple group analysis approach. Journal of Hospitality \& Tourism Research, 35(2), 191-212.

Cole, T. S., Crompton, J. L., \& Willson, V. L. (2002). An empirical investigation of the relationships between service quality, satisfaction and behavioral intentions among visitors to a wildlife refuge. Journal of Leisure Research, 34(1), 1-24.

Conner, M. T., \& Sparks, P. (1996). Applying the theory of planned behaviour. In M. T. Conner \& P. Norman (Eds.), Predicting health behaviour (pp. 121-161). Milton Keynes: Open University Press.

Crotts, J. C., \& Erdmann, R. (2000). Does national culture influence consumers' evaluation of travel services? A test of Hofstede's model of cross-cultural differences. Managing Service Quality: An International Journal, 10(6), 410-419.

Davidow, M. (2003). Organizational responses to customer complaints: What works and what doesn't. Journal of Service Research, 5(3), 225-250. 
Debasish, S. S., \& Dey, M. S. (2015). Customer perceptions of service quality towards luxury hotels in Odisha using SERVQUAL model. International Journal of Research in Business Studies and Management, 2(9), 1-9.

Dhar, R. L. (2015). Service quality and the training of employees: The mediating role of organizational commitment. Tourism Management, 46(complete), 419-430.

Duffy, D. L. (2003). Internal and external factors which affect customer loyalty. Journal of Consumer Marketing, 20(5), 480-485.

Engs, R. C., Diebold, B. A., \& Hanson, D. J. (1996). The drinking patterns and problems of a national sample of college students, 1994. Journal of Alcohol and Drug Education, 41, 13-33.

Fornell, C., Johnson, M. D., Anderson, E. W., Cha, J., \& Bryant, B. E. (1996). The American customer satisfaction index: Nature, purpose, and findings. Journal of Marketing, 60(4)7-18.

Fornell, C. (1992). A national customer satisfaction barometer: The Swedish experience. Journal of Marketing, 56(1), 6-21.

Frochot, I., \& Hughes, H. (2000). HISTOQUAL: The development of a historic houses assessment scale. Tourism Management, 21(2), 157-167.

Gallo, J. J., Rabins, P. V., \& Anthony, J. C. (1999). Sadness in older persons: 13-year follow-up of a community sample in Baltimore, Maryland. Psychological Medicine, 29(02), 341350 .

Gillet, S., Schmitz, P., \& Mitas, O. (2016). The snap-happy tourist: The effects of photographing behavior on tourists' happiness. Journal of Hospitality \& Tourism Research, 40(1), 3757.

Hampton, N. Z., \& Marshall, A. (2000). Culture, gender, self-efficacy, and life satisfaction: A comparison between Americans and Chinese people with spinal cord injuries. ProQuest. Retrieved March 13, 2016, from http://search.proquest.com/openview/7ecaab4c7e79118f0e5ba642365650a6/1?pqorigsite $=$ gscholar

Hansen, K. V. (2014). Development of SERVQUAL and DINESERV for measuring meal experiences in eating establishments. Scandinavian Journal of Hospitality and Tourism, 14(2), 116-134.

Helliwell, J. F., Layard, R., \& Sachs, J. (2015). World happiness report 2015. New York: Sustainable Development Solutions Network.

Heung, V. C., \& Lam, T. (2003). Customer complaint behaviour towards hotel restaurant services. International Journal of Contemporary Hospitality Management, 15(5), 283289.

Hofstede, G., \& Hofstede, G. J. (2005). Cultures and organizations: Software of the mind (2nd ed.). New York, NY: McGraw-Hill.

Hofstede, G. (2001). Culture's consequences (2nd ed.). Thousand Oaks, CA: Sage.

Hsu, C. H. (2000). Determinants of mature travels' motor-coach tour satisfaction and brand loyalty. Journal of Hospitality \& Tourism Research, 24, 223-238.

Huang, J. H., Huang, C. T., \& Wu, S. (1996). National character and response to unsatisfactory hotel service. International Journal of Hospitality Management, 15(3), 229-243.

Hudson, S., \& Ritchie, J. B. (2001). Cross-cultural tourist behavior: An analysis of tourist attitudes towards the environment. Journal of Travel \& Tourism Marketing, 10(2-3), 122. 
Humara, M. J., \& Sherman, M. F. (1999). Brief report situational determinants of alcohol abuse among Caucasian and African-American college students. Addictive Behaviors, 24(1), $135-138$.

Hyde, K. F., \& Lawson, R. (2003). The nature of independent travel. Journal of Travel Research, 42(1), 13-23.

Jacoby, J., \& Jaccard, J. J. (1981). The sources, meaning, and validity of consumer complaint behavior: A psychological analysis. Journal of Retailing, 57(3), 4-24.

Johns, N., \& Gyimóthy, S. (2002). Market segmentation and the prediction of tourist behavior: The case of Bornholm, Denmark. Journal of Travel Research, 40(3), 316-327.

Jöreskog, K. G., \& Goldberger, A. S. (1975). Estimation of a Model with Multiple Indicators and Multiple Causes of a Single Latent Variable. Journal of the American Statistical Association, 70(351a), 631-639.

Kandampully, J., \& Suhartanto, D. (2000). Customer loyalty in the hotel industry: The role of customer satisfaction and image. International Journal of Contemporary Hospitality Management, 12(6), 346-351.

Kang, S.-M., Shaver, P. R., Sue, S., Min, K.-H., \& Jing, H. (2003). Culture-specific patterns in the prediction of life satisfaction: Roles of emotion, relationship quality, and self-esteem. Personality and Social Psychology Bulletin, 29(12), 1596-1608.

Karatepe, O. M. (2006). Customer complaints and organizational responses: The effects of complainants' perceptions of justice on satisfaction and loyalty. International Journal of Hospitality Management, 25(1), 69-90.

Kastenholz, E., Carneiro, M. J., \& Eusébio, C. (2005). The impact of socio-demographics on tourist behavior-analyzing segments of cultural tourists visiting Coimbra. Atlas Cultural Tourism Research Project.

Keng, K. A., Richmond, D., \& Han, S. (1995). Determinants of consumer complaint behaviour: A study of Singapore consumers. Journal of International Consumer Marketing, 8(2), 59-76.

Kim, H., \& Stepchenkova, S. (2016). Understanding destination personality through visitors' experience: A cross-cultural perspective. Journal of Destination Marketing \& Management, 6, 416-425.

Kim, Y. G., \& Eves, A. (2012). Construction and validation of a scale to measure tourist motivation to consume local food. Tourism Management, 33(6), 1458-1467.

Knox, G., \& van Oest, R. (2014). Customer complaints and recovery effectiveness: A customer base approach. Journal of Marketing, 78(5), 42-57.

Kozak, M., \& Rimmington, M. (1999). Measuring tourist destination competitiveness: Conceptual considerations and empirical findings. International Journal of Hospitality Management, 18(3), 273-283.

Laroche, M., Ueltschy, L. C., Abe, S., Cleveland, M., \& Yannopoulos, P. P. (2004). Service quality perceptions and customer satisfaction: Evaluating the role of culture. Journal of International Marketing, 12(3), 58-85.

Lepsito, L. R., \& McCleary, K. W. (1988). The effect of multiple measures of age in segmenting hotel markets. Council on Hotel, Restaurant, and Institutional Education, August, 91-99.

Lim, Y.-J. (2014). Relations between virtues and positive mental health in a Korean population: A Multiple Indicators Multiple Causes (MIMIC) model approach. International Journal of Psychology, 50(4), 272-278.

Liou, J. J., Tzeng, G. H., Hsu, C. C., \& Yeh, W. C. (2012). Reply to “Comment on using a 
modified grey relation method for improving airline service quality”. Tourism Management, 33(3), 719-720.

Litvin, S. W., Crotts, J. C., \& Hefner, F. L. (2004). Cross-cultural tourist behaviour: A replication and extension involving Hofstede's uncertainty avoidance dimension. International Journal of Tourism Research, 6(1), 29-37.

Loker-Murphy, L., \& Pearce, P. L. (1995). Young budget travelers: Backpackers in Australia. Annals of Tourism Research, 22(4), 819-843.

Lowyck, E., Langenhove, L., \& Bollaert, L. (1990). Typologies of tourist roles. In P. Johnson \& B. Thomas (Eds.), Choice and demand in tourism (pp. 13-32). London, UK: Mansell.

Maltritz, D., Bühn, A., \& Eichler, S. (2011). Modelling country default risk as a latent variable: A multiple indicators multiple causes approach. Applied Economics, 44(36), 4679-4688.

Maoz, D. (2007). Backpackers' motivations the role of culture and nationality. Annals of Tourism Research, 34(1), 122-140.

Masiero, L., Pan, B., \& Heo, C. Y. (2016). Asymmetric preference in hotel room choice and implications on revenue management. International Journal of Hospitality Management, 56, 18-27.

Mattila, A. S., Apostolopoulos, Y., Sonmez, S., Yu, L., \& Sasidharan, V. (2001). The impact of gender and religion on college students' spring break behavior. Journal of Travel Research, 40(2), 193-200.

Meng, F., Tepanon, Y., \& Uysal, M. (2008). Measuring tourist satisfaction by attribute and motivation: The case of a nature-based resort. Journal of Vacation Marketing, 14(1), 4156.

Moreira, A. C., \& Silva, P. M. F. D. (2016). Complaint behaviour by third parties: Exploring service quality, customer satisfaction and word-of-mouth in health clubs. International Journal of Sport Management and Marketing, 16(3-6), 152-171.

Neal W. D. (2000). Market segmentation. In C. Chakrapani (Ed.), Marketing research: State-ofthe-art perspectives: Handbook of the American Marketing Association \& Professional Marketing Research Society (pp. 375-399). Chicago, IL: American Marketing Association.

Ngai, E. W., Heung, V. C., Wong, Y. H., \& Chan, F. K. (2007). Consumer complaint behaviour of Asians and non-Asians about hotel services: An empirical analysis. European Journal of Marketing, 4l(11/12), 1375-1391.

Nikolaidis, D., Chrysikou, S. C., \& Alexandris, K. (2016). Testing the relationship between hotel service quality and hotel brand personality. International Journal of Hospitality and Event Management, 1(4), 355-369.

Núñez-Serrano, J. A., Turrión, J., \& Velázquez, F. J. (2014). Are stars a good indicator of hotel quality? Asymmetric information and regulatory heterogeneity in Spain. Tourism Management, 42, 77-87.

Oberoi, U., \& Hales, C. (1990). Assessing the quality of the conference hotel service product: Towards an empirically based model. Service Industries Journal, 10(4), 700-721.

Oppermann, M. (1995). A model of travel itineraries. Journal of Travel Research, 33(4), 57-61.

Ostrowski, P. L., O'Brien, T. V., \& Gordon, G. L. (1993). Service quality and customer loyalty in the commercial airline industry. Journal of Travel Research, 32(2), 16-24.

Parasuraman, A., Zeithaml, V. A., \& Berry, L. L. (1985). A conceptual model of service quality and its implications for future research. Journal of Marketing, 49(4), 41-50.

Parasuraman, A., Zeithaml, V. A., \& Berry, L. L. (1988). SERVQUAL: A multiple-item scale 
for measuring consumer perceptions of service quality. Journal of Retailing, 64(1), 12-40.

Parasuraman, A., Zeithaml, V. A., \& Berry, L. L. (1991). Refinement and reassessment of the SERVQUAL scale. Journal of Retailing, 67(4), 420-449.

Peters, T. (1988). Thriving on chaos. New York: Alfred A. Knopf.

Pizam, A., \& Jeong, G. H. (1996). Cross-cultural tourist behavior: Perceptions of Korean tourguides. Tourism Management, 17(4), 277-286.

Proitsi, P., Hamilton, G., Tsolaki, M., Lupton, M., Daniilidou, M., Hollingworth, P., Archer, N., Foy, C., Stylios, F., McGuinness, B., Todd, S., Lawlor, B., Gill, M., Brayne, C., Rubinsztein, D. C., Owen, M., Williams, J., Craig, D., Passmore, P., Lovestone, S., \& Powell, J. F. (2011). A multiple indicators multiple causes (MIMIC) model of behavioural and psychological symptoms in dementia (BPSD). Neurobiology of Aging, 32(3), 434-442.

Rahman, T., Mittelhammer, R. C., \& Wandschneider, P. R. (2011). Measuring quality of life across countries: A multiple indicators and multiple causes approach. Journal of SocioEconomics, 40(1), 43-52.

Rogers, J. C., Ross, S. C., \& Williams, T. G. (1992). Personal values and purchase dissatisfaction response. Journal of Consumer Satisfaction, Dissatisfaction and Complaining Behavior, $5(1), 81-92$.

Rose, A. K., \& Spiegel, M. M. (2011). Cross-country causes and consequences of the crisis: An update. European Economic Review, 55(3), 309-324.

Ryglová, K., Vajčnerová, I., \& Šácha, J. (2016). Destination quality perception in the context of different behavioural characteristics of visitors. Czech Journal of Tourism, 5(1), 5-20.

Saad, G., Gill, T., \& Nataraajan, R. (2005). Are laterborns more innovative and nonconforming consumers than firstborns? A Darwinian perspective. Journal of Business Research, 58(7), 902-909.

Sabiote-Ortiz, C. M., Frías-Jamilena, D. M., \& Castañeda-García, J. A. (2016). Overall perceived value of a tourism service delivered via different media: A cross-cultural perspective. Journal of Travel Research, 55(1), 34-51.

Siegel, D. (1997). The impact of computers on manufacturing productivity growth: A multipleindicators, multiple-causes approach. Review of Economics and Statistics, 79(1), 68-78.

Song, H., \& Chon, K. (2015). The Hong Kong tourist satisfaction index and tourism service quality index 2015. The Hong Kong Polytechnic University.

Song, H., van der Veen, R., Li, G., \& Chen, J. L. (2012). The Hong Kong tourist satisfaction index. Annals of Tourism Research, 39(1), 459-479.

Suh, E., Diener, E., Oishi, S., \& Triandis, H. C. (1998). The shifting basis of life satisfaction judgments across cultures: Emotions versus norms. Journal of Personality and Social Psychology, 74(2), 482-493.

Swanson, K. K., \& Horridge, P. E. (2004). A structural model for souvenir consumption, travel activities, and tourist demographics. Journal of Travel Research, 42(4), 372-380.

Tripathi, G., \& Dave, K. (2014). Exploration of service quality factors in restaurant industry: A study of selected restaurants in New Delhi region. Journal of Services Research, 14(1), $9-26$.

Tsaur, S. H., Yen, C. H., \& Chen, C. L. (2010). Independent tourist knowledge and skills. Annals of Tourism Research, 37(4), 1035-1054.

Wang, Y., So, K. K. F., \& Sparks, B. A. (2017). Technology readiness and customer satisfaction with travel technologies: A cross-country investigation. Journal of Travel Research, 
56(5), 563-577.

Wang, W., Chen, J. S., Fan, L., \& Lu, J. (2012). Tourist experience and wetland parks: A case of Zhejiang, China. Annals of Tourism Research, 39(4), 1763-1778.

Weiermair, K. (2000). Tourists' perceptions towards and satisfaction with service quality in the cross-cultural service encounter: Implications for hospitality and tourism management. Managing Service Quality: An International Journal, 10(6), 397-409.

Wu, H. C., \& Cheng, C. C. (2013). A hierarchical model of service quality in the airline industry. Journal of Hospitality and Tourism Management, 20(complete), 13-22.

Yoon, Y., \& Uysal, M. (2005). An examination of the effects of motivation and satisfaction on destination loyalty: A structural model. Tourism Management, 26(1), 45-56.

Yu, H. S., Zhang, J. J., Kim, D. H., Chen, K. K., Henderson, C., Min, S. D., \& Huang, H. (2014). Service quality, perceived value, customer satisfaction, and behavioral intention among fitness center members aged 60 years and over. Social Behavior and Personality: An International Journal, 42(5), 757-767.

Zeithaml, V. A. (1987). Defining and relating price, perceived quality, and perceived value, Report No, 87-101, Cambridge, MA: Marketing Science Institute. 